\title{
A JÖVŐ VENDÉGLÁTÁSA, A VENDÉGLÁTÁS JÖVÖJE REGIONÁLIS KUTATÁS AZ ÉRINTETT VÁLLALKOZÁSOK KÖRÉBEN
}

\author{
${ }^{1}$ Nagy Dávid $-{ }^{2}$ Gonda Tibor $-{ }^{3}$ Háló Krisztián $-{ }^{4}$ Dán Andrea \\ ${ }^{1}$ PhD hallgató, Pécsi Tudományegyetem Földtudományok Doktori Iskola,david@info- \\ partner.hu \\ ${ }^{2}$ PTE KTK MTI, gonda.tibor@ktk.pte.hu \\ ${ }^{3}$ PTE KTK MTI, halo.krisztian@ktk.pte.hu \\ ${ }^{4}$ PTE KTK, dan.andrea@pte.hu
}

DOI: $10.15170 / T V T .2021 .06 .02 .06$

\begin{abstract}
Absztrakt
A GINOP-5.3.5-18-2019-00104 számú projekt keretében 2020. október 1. - november 10. között kérdőíves felmérést végeztünk a Dél-Dunántúli Régió vendéglátáshoz köthető cégeinek vezetői és munkatársai körében, aminek kapcsán cégének müködési kihívásaira és a hazai és nemzetközi vendéglátás jövőjével kapcsolatos véleményére voltunk kíváncsiak. Az elmúlt és az idei év rendkívül nehéz helyzet elé állította az ágazat dolgozóit. Éppen ezért különösen fontos látni azt, hogy hogyan vélekednek Ök, a szakma képviselői a vendéglátás jövőjéről.
\end{abstract}

Kulcsszavak: vendéglátás, fogyasztói trendek, vállalkozások, jövö

\begin{abstract}
In the framework of the project GINOP-5.3.5-18-2019-00104, a questionnaire survey was conducted from 1 October to 10 November 2020 among the executives and staff of the South Transdanubian companied engaged in the hospitality sector, with the aim of exploring the operational challenges of the companies and the opinions of the respondents about the future prospects of the Hungarian and international hospitality industry. Last year and this year have posed an extremely difficult challenge for the employees of this sector, which makes it especially important to get to know their views, the views of the catering professionals, about the future of the hospitality sector.
\end{abstract}

Keywords: hospitality, consumer trends, business, future 


\section{Bevezetés}

A vendéglátás több ezer éves múltra tekint vissza. Dinamikus, folyton változó, átalakuló tevékenység, amely mindig igazodik az adott kor elvárásaihoz, divatjához, a fogyasztói igényekhez. Az elmúlt évtizedekben látványos fejlődésen ment keresztül, a gazdasági jelentősége is folyamatosan nő. A vendéglátás a turizmussal szoros kapcsolatban áll, a turisztikai kínálat nélkülözhetetlen része. Napjainkban egyfajta gasztroforradalomnak lehetünk a tanúi, amelyben a minőségi vendégfogadás feltételei mellett, a minőségi, helyi és a szezonális alapanyagok kapják a kiemelt szerepet. (GONDA et al. 2020) A mai magyar vendéglátásnak igen nagy az innovációs képessége. Ezért bizakodni lehet abban, hogy az ágazatot súlytó 2020-as évi koronavírus-járvány gazdasági következményeit hamar kiheveri (CSAPÓ - LÖRINCZ 2020, SOÓS 2020), és az azt megelőző időszak fejlődési pályájára tér vissza. A vendéglátás minősége azonban nem csak gazdasági kérdés. A színes és különleges, egyedi gasztronómiai kínálatnak a turizmusban is növekvő jelentősége van (GONDA 2014). Napjainkban a kérdés már az, hogy a vendéglátás sokszínü kínálata valóban csak a szolgáltatások között vehetö-e figyelembe, vagy a turisztikai termék központi elemét jelentő, vonzerő-kategóriaként is. Úgy véljük, a vendéglátás egyes megjelenési formái már-már olyan érdeklödésre tartanak számot, hogy egyértelmüen a vonzerök kategóriájába lehet sorolni ezeket.

\section{Szakirodalmi áttekintés}

Napjainkban a gasztronómia iránti érdeklődést a média is folyamatosan erősíti (GULD 2020). A magyar gasztronómia kínálati oldala rendkívül sokszínü, és nagy hagyománnyal rendelkezik. (GONDA-KAPOSI 2019), a helyi lakosság igényeinek kielégítése mellett már a turizmuson belül betöltött szerepe is kiemelt fontosságúvá vált. Az érdeklődés az egészséges, bit-minőségünek számító táplálékok iránt egyre nő. Szerencsére a turizmus szereplői is érzékelik ezt a trendet, és szaporodnak a helyi termékekre és vadnövényekre épülö egyedi kínálati elemek (NEULINGER et al. 2020). A legutolsó évtizedben a helyi termékek és a vadnövények a csúcsgasztronómiában is szerephez jutnak (például medvehagyma, erdei gombák, gyékényhajtás, madársóska, vízitorma) és mára a gyüjtögetett alapanyagok használata a gasztronómiai trendek között is szerepel (POPOVICS et al. 2020, SZAKÁLY et al. 2020). A korszerü vendéglátás nem fordít hátat a múltnak, gasztrokulturális örökségünk ápolása napjainkban a piac által is értékelt kiemelt fontosságú törekvés. Emellett meghatározóak a gasztronómiai programok, a tematikus utak kínálatai, valamint a gasztrofesztiválok (ZÁVODI- SZABÓ 2019, HARSÁNYI - HLÉDIK 2020). Az éttermek kínálatából kitűnnek az „újhullámos” éttermek, az ún. „street food” ételárusító helyek és a modern „fine dining”, vagy a modern és a hagyományos konyhát ötvöző éttermek (GONDA et al. 2020). Freyer besorolása szerint a vendéglátás az ún. turisztikai ,peremgazdaság” része, mivel alapvetően nem turisztikai igények eredményezték a vendéglátás kialakulását, és nem tipikusan a turisták igényére építve alakítják ki kínálatukat, de a turistákra, mint célközönségre számítanak.. Ugyanakkor Freyer lassan két évtizeddel ezelőtti gondolata a turizmus globálissá válásával, a jelentős mértékű tömegturizmusra épülő desztináció létrejöttével felülbírálatra is szorul, hiszen nyilvánvaló, hogy egyes fogadóterületeken a vendéglátás is 100\%-ban az odaérkező turisták speciális „turisztikai” igényeinek a kielégítését szolgálja, és így ugyanolyan része a turizmusgazdaságnak, mint a szállás-szolgáltatás. Ha a turizmus termékszemléletủ megközelítésére gondolunk, akkor ugyancsak a szállás-szolgáltatásokkal azonos csoportba, az ún. elsődleges szuprastruktúrába kell sorolnunk a vendéglátást (GONDA 2016). 
A gasztronómiai-vendéglátóipari kínálat esetében napjainkban nem is ez a fő kérdés, hanem az, hogy a vendéglátás kínálata valóban csak a szolgáltatások között vehetö-e figyelembe, vagy a turisztikai termék központi elemét jelentő vonzerő kategóriájánál is. Azaz a kérdés úgy tehető fel, hogy lehet-e, és ha igen, milyen mértékig önmagában turisztikai vonzerö a vendéglátás által létrehozott gasztronómiai kínálat?

A vendéglátás az elmúlt évtizedekben növelte részesedését mind a foglalkoztatásból, mind az elöállított hozzáadott érték tekintetében. A fogyasztói trendek vizsgálata is azt támasztja alá, hogy az ágazat jelentősége a továbbiakban is erősödni fog (TÖRŐCSIK - CSAPÓ 2018). A „szálláshelyek és vendéglátás” kategóriája az Európai Unióban 2017-ben a teljes foglalkoztatás $8,1 \%$-át adta és az összes vállalkozás 8,3\%-a ebben az ágazatban dolgozott (https://ec.europa.eu/eurostat/). A vendéglátás önmagában a GDP mintegy 4\%-át adta már az új évezred legelején (FRIDDLE et al. 2001), és azóta évente gyors, akár 5-6\%-os növekedési ütemet mutatott különbözö gazdasági és demográfiai trendeknek és változásoknak, illetve technológiai fejlesztéseknek, valamint a munkaerőpiacon bekövetkezett változásoknak köszönhetően. (GONDA et al. 2020) Alapvetően a demográfiai változások azok, amelyek a vendéglátás (és tágabb értelemben a teljes élelmiszer-gazdaság) változásait előidézik: ahogy a „baby boomer” generáció középkorúvá vált, egyre kevesebb ideje maradt a fözésre és gyermekeik sem tüntek igazán érdeklődőnek az ételkészítés iránt. A globalizálódó, beszükülő világ, a karnyújtásnyi közelségbe került új kultúrák, ételek, ízek ráadásul a kínálati oldalt is egyre vonzóbbá tették. A munkaerőpiaci változások pedig a kényelmi ételek (félkész- és készételek) iránti keresletet alapozták meg (FRIDDLE et al. 2001). Ez a folyamat hazánkban is tetten érhető. A vendéglátás további térnyerése, népszerüségének növekedése prognosztizálható. A gasztronómia napjainkban ez érdeklődés középpontjában áll. Michalkó (2012) a gasztronómiát az ember által létrehozott vonzerőként értelmezi, ahol a gasztronómia az egyénnek okozott mindennapi örömöt kiegészíti a fogyasztás során megélt különleges környezet és ízpárosítások együttes hatása során megvalósuló extra élménnyel. Ilyen például egy minősítő rendszer által értékelt étterem meglátogatása, vagy egy nemzeti konyha felkeresése.

A gasztronómia fogalma a 19. század közepén fogalmazódott meg. Ám maga a gasztronómiai turizmus fogalmára a mai napig sem találtak egyöntetű meghatározást. Ez a kutatók széleskörü értelmezésének köszönhető. Az értelmezés során különválasztják a gourmet turizmus és gasztronómiai fesztiválok keltette érdeklődést, illetve a gasztronómia szerepét az idegenforgalomban (HALL - SHARPLES 2003). Legjobban Hall és Sharples 2003-as megfogalmazása határolja le a gasztroturizmus definícióját. Eszerint a gasztroturizmus egy tapasztalati utazás egy gasztronómiai régióba. Magába foglalja a főzőbemutatók, gasztrofesztiválok, termelői vásárok és helyi termelők meglátogatását is. Ide tartozik még a minőségi ételek és borok kóstolása, illetve minden olyan tevékenység, mely a gasztronómiával összefüggésbe hozható. A gasztroturizmus olyan turisztikai célú utazást jelent, amely során a turista elérni kívánt célja, hogy maradandó és emlékezetes gasztronómiai élményt szerezzen a desztinációra jellemző ételek és italok által (SZIVA et al. 2017) A Magyar Turisztikai Ügynökség (2017) által megfogalmazott definíció írja le a gasztronómiai turizmus nemzetközileg elfogadott meghatározását: „A gasztronómiai turizmus olyan turisztikai termék, melynek során a látogató fő motivációja a felkeresett célterületre jellemző ételek és italok megízlelése, a nemzeti és tájjellegü konyha kipróbálása, a desztináció vendéglátási tradícióival való megismerkedés, de megjelenhet az igény a gasztronómiai különlegességek elkészítési módjának elsajátítása iránt is. Motivációt jelenthet továbbá egy-egy híres vendéglátóipari létesítmény - étterem, mühely, gyár - felkeresése vagy speciális ételekhez, italokhoz kötődő fesztiválok, versenyek meglátogatása." (MTÜ 2017 156.o) A gasztronómiai turizmus népszerüsége világszerte növekvő tendenciát mutat. Folyamatosan új és innovatív turisztikai termékek jelennek meg a nemzetközi és a hazai piacon egyaránt. 
Magyarországon is, mint nemzetközileg is fontos keresleti tényezőként jelennek meg a gasztroturisták. Ezek a vendégek kiemelt figyelmet fordítanak utazásaik során a gasztronómiai minőségre és az autentikus helyi gasztronómia értékeire. (VARGÁNÉ et al. 2015).

A gasztronómia egyre nagyobb szerepet tölt be az emberek életében. Manapság már nem csak a túlélés eszköze az étkezés, hanem egyfajta élvezeti értéket közvetít, illetve presztízs szerepet is betölt. A turizmusban ma már önmagában is megállja a helyét, mint önálló turisztikai forma. Ezt elsősorban az itthon eröteljes fejlődésen átesett borturizmusnak köszönheti. Ennek legföbb motivációja a borvidékek meglátogatása, a borok helyben történő kóstolása és megvásárlása, illetve maga a borkészítés elméletének megismerése egy szakember segítségével. Ide sorolhatjuk a szüreti és borfesztiválokat egyaránt. Manapság érezhető, hogy a turizmus rendszerén belül a vendéglátás egyre jelentősebb szerepet tölt be. Míg régebben kiegészítő szolgáltatásként jelent meg a szállás mellett, addig mára már önálló vonzerőként is müködik. Az emberek az utazásaik során általában az adott területre jellemző ételeket- és italokat szeretnék megkóstolni és nem olyanokat, mint odahaza. (GONDA et al. 2020)

Az ételek és italok megismerése és a hozzájuk kapcsolódó területek felfedezése, mint elsődleges motiváció az utazási döntés során nagy jelentőséggel bír. Egy utazással egybekötött étteremlátogatás ma már a gasztroturizmus divatos kategóriájába tartozik. A turisztikai termék részét képezheti minden olyan szolgáltatás igénybevétele is, mint például egy fózőiskolai tanfolyam vagy a helyi termelői piac felkeresése. Emellett az adott tájegységre jellemző ételek- és italok fogyasztása lényeges eleme lehet a városi és a falusi turizmusnak egyaránt, viszont nem elsődleges szempont az utazási döntés meghozatalában. A borturizmus a gasztroturizmus egyik altípusának tekinthető, mely a bortermelő vidékek, pincék, borfesztiválok, borbemutatók látogatását foglalja magába. Ebben az esetben a borkóstolás és a borvidék megismerése az elsődleges motiváció az utazási döntésben. A gasztronómiai turizmus elemei közé sorolhatjuk a természeti környezetet, a történelemet, a kultúrát, a hagyományokat és a helyi konyhát is. A gasztroturizmus alapját a termék, vagyis az adott tájegységre jellemző ételek és italok képezik.

Mára az éttermi turizmus a gasztroturizmus egyik jelentős mozgatórugója. Éttermi turizmus alatt olyan turisztikai termékek érthetőek, melynek igénybevételére a fogyasztó elsődleges motivációja kimondottan egy étterem meglátogatása. Természetesen nem elhanyagolható az a tény, hogy a borturizmus a legjelentősebb terület a gasztronómiai turizmuson belül. Ám azt is meg kell jegyezni, hogy a borturizmus és az éttermi turizmus szorosan kapcsolódik egymáshoz. Például a Villányban található Sauska 48 nevü étterem megér egy utazást, ha a környéken tartózkodunk, ám ha Villányba látogatunk, akkor szinte kötelező a helyi borokat is megkóstolni.

Hazánkban ma már gyakorlatilag egymást érik az igényes éttermek, nem csak Budapesten és a Balaton partján, de egyre több vidéki, akár kisebb településen is. Ezeket egyre többször fémjelzik igazi sztároknak számító séfek. Természetesen nem csak a sztárséfekkel tünnek ki ezek a helyek, hanem a professzionalitásukkal, az európai színvonalat kínáló ételkölteményeikkel, minőségi boraikkal, melyek legjobb esetben helyi termelőktől származnak és a tökéletes alapanyagokkal. Ám a legtöbben még mindig a budapesti éttermeket veszik célba, ha szeretnének kipróbálni valami új gasztronómiai fogást. Szerencsére mára már egyre több vidéki városban megtalálható egy vagy több olyan vendéglő, bisztró vagy akár cukrászda, mely különleges menüsorokat kínál a vendégek számára. A hagyományos ételek mellett egyre több az olyan modern vagy újragondolt étel, melyeket a helyi alapanyagok segítségével megmutathatnak az érdeklődőknek. Fontos kiemelni azt is, hogy egyre több olyan vidéki étterem van, amely kimondottan a helyi alapanyagokra koncentrál és a helyi termelőkkel összefogva állítja össze a szezonális menüsorokat. Nem mellesleg ezzel támogatva is a helyi gazdaságot. 


\section{A kutatás eredményeinek bemutatása}

A jelen tanulmányunkat megalapozó kérdőíves vizsgálat a Dél-Dunántúli régió területére terjedt ki. Első körben közvetlenül közel 800 címre lett eljuttatva a kérdöív, de az alacsony kitöltési hajlandóság miatt több szakmai szervezet segítségét is kellett kérni a tervezett 200 db kitöltési szám eléréséhez. A vendéglátásban érintettek elérésében közremüködött a KISOSZ Baranya Megyei Egyesülete, az Orfüi Turisztikai Egyesület, a Dél-Dunántúli Ökoturisztikai Klaszter, A PécsMecseki és a Villányi Borút Egyesület. Nagyon hasznos segítséget kaptunk a PTE KPVK üzleti szakoktató képzésében részt vevő gyakorló szakemberektől, és a Baranya megye és Pécs - Európa Gasztronómiai Régiója 2024 kezdeményezés önkénteseitől. Összesen 210 db kérdöív került kitöltésre. A vizsgálat aktualitását az adja, hogy a 2020 szeptemberében lehatárolt Pécs-Villány turisztikai térség pozícionálási stratégiájában a kulturális turizmus mellett (GÁSZNÉ BÖSZ 2020) a gasztro- és borturizmus kap kiemelt szerepet a desztináció turizmusának a fejlesztésében (PálfiAubert 2019). Jelen tanulmány célja a kutatási eredmények alap elemzése és ezen eredmények ismertetése, illetve az eredményekhez való hozzáférés biztosítása az érdeklődők számára.

\subsection{A kitöltők adatai}

A kérdőív első szakaszában a különböző cégek adatairól tettünk fel kérdéseket, melyek a következőkre irányultak: a cégek vendéglátáshoz kapcsolódó tevékenységei, a cégek alapításának ideje, a cégek foglalkoztatottjainak létszáma, illetve a kérdőívet kitöltő egyén cégben betöltött szerepe. A válaszok alapján kiderül, hogy a legtöbb megkérdezett $(31,1 \%)$ alkalmazotti minőségben töltötte ki kérdöívünket. További $25 \%$-uk a vendéglátásban érintett cég tulajdonosaként, $22,4 \%$ a vendéglátásban érintett cég vezetőjeként, 13,3\%-uk hallgatóként, 3,1\%uk egyesületi tagként, $2 \%$-uk civil szervezet munkatársaként, illetve 1,5-1,5\%-uk önkormányzatként vagy szakemberként töltötte ki a kérdőívet. A bevont egyetemi hallgatók levelező képzésben az üzleti szakoktató alapszakot végzik, és nagy részük közvetlenül kötődik a vendéglátáshoz. A civil szervezeti munkatársak is turisztikai szervezetekben dolgoznak (Borút Egyesület, TDM, stb.), így nekik is megvan a szükséges rálátásuk az ágazat helyzetére. A cégek vendéglátáshoz kapcsolódó tevékenységével kapcsolatban elmondható, hogy a kérdőívet kitöltők cégeinek 34,5\%-a melegkonyhás vendéglátóhely üzemeltetésével, 31,6\%-uk rendezvényszervezéssel, 25,4\%-uk kávézó üzemeltetésével, 22-22\%-uk catering szolgáltatásokkal és szálláshely szolgáltatáshoz kapcsolódó vendéglátással, 16,9\%-uk PR és marketing tevékenységgel, $16,4 \%$ büfé üzemeltetésével foglalkozik. Rajtuk kívül vannak még, akik ételkiszállítás szolgáltatással $(11,9 \%)$ pályázati tanácsadással és szakértéssel $(7,9 \%)$, sörözö, borozó vagy kocsma üzemeltetésével $(2,3 \%)$, ital nagykereskedés üzemeltetésével $(0,6 \%)$, borkóstolással $(0,6 \%)$, vagy presszó üzemeltetésével $(0,6 \%)$ foglalkoznak. (2. ábra)

A következő kérdés, melyre választ kellett adniuk a kitöltőknek a cég alapítására vonatkozott, melyhez valamilyen minőségben kötődnek. Ahogyan az várható volt, széles skálán érkeztek válaszok a kérdésre. 1980-tól napjainkig közel minden évben történt cégalapítás. A kutatásban szereplö cégek közül a legtöbbet a 2010-es (8,3\%), az 1998-as (7\%) és a 2019-es (6,4\%) évben alapították meg. (1. ábra)

Az alapítást követően arra is válaszolni kellett a megkérdezetteknek, hogy az adott cég összesen hány fö́t foglalkoztat. Egy viszonylag széles skála alakult ki itt is a válaszok alapján, melyben egy foglalkoztatottól akár ötven foglalkoztatottig is terjedhet a létszám. Ezen felül akadt egy-egy olyan cég is, mely 300-nál is több egyént alkalmaz, sőt akadt egy olyan is, amelynek az alkalmazottainak a száma közel 2800. Ezzel szemben a legtöbb cég esetében egytől hatig terjed a foglalkoztatottak köre. A várakozásnak megfelelően a válaszadók mintegy kétharmada 10 főnél kevesebb alkalmazottat foglalkoztató mikrovállalkozást képviselt. (2. ábra) 


\section{1. ábra: A cégek alapításának ideje (n=157)}

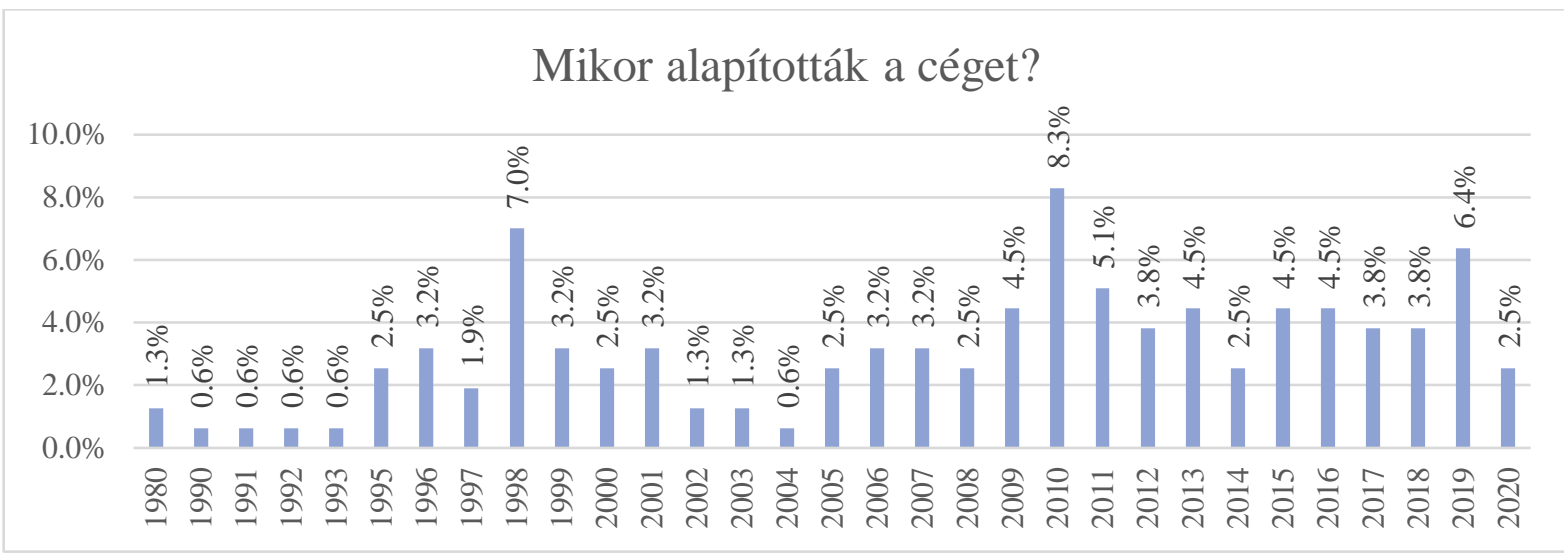

Forrás: Saját szerkesztés

\section{2. ábra: A cégek foglalkoztatottainak létszáma ( $n=164)$}

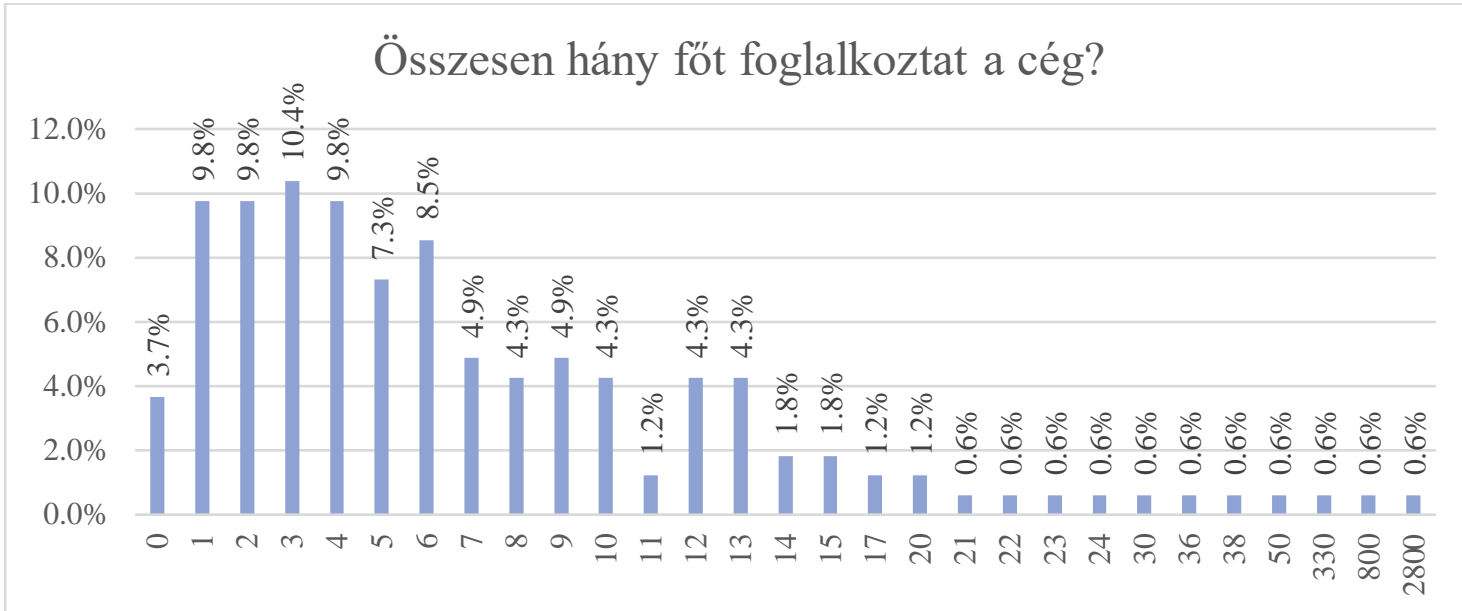

Forrás: Saját szerkesztés.

Összefoglalásként elmondható, hogy a kérdőívet kitöltők leginkább alkalmazotti, vendéglátásban érintett cég vezetői vagy tulajdonosi minőségben szerepelnek; tevékenységüket tekintve föleg a melegkonyhás vendéglátóhelyek, kávézók üzemeltetésével és rendezvényszervezéssel foglalkozó cégek vesznek részt a kutatásban; alapítás tekintetében megoszlik a kép; foglalkoztatást tekintve pedig főként a maximum 13 főt foglalkoztató cégek szerepelnek a tanulmányban.

2.2 A jövő vendéglátásának értékelése

A következő fejezetben a régióban fellelhető cégek előtt álló kihívásokat, a tervben lévő fejlesztéseket, illetve a vendéglátásra ható trendeket kívánjuk felmérni. Elsőként arra kellett választ adniuk a kitöltőknek, hogy szerintük mik a legfontosabb, a cég elött álló kihívások a közeljövőben. A megadott szempontok közül hármat választhattak ki. A 3. ábrán jól látható, hogy a legfontosabb kihívásnak egyértelmüen a COVID miatt kialakuló fizetőképes kereslet visszaesését $(22,8 \%)$ tartották a megkérdezettek. Fontos kihívás lehet még a közeljövőben a vírushelyzettel kapcsolatos jogszabályoknak, elöírásoknak és korlátozásoknak való megfelelés (16,5\%), a bizonytalan gazdasági környezet (16\%), a munkatársak megfelelö bérezésének megteremtése (14,3\%), illetve a gyors, rugalmas reagálás és az alkalmazkodás az új helyzetekhez (11,9\%). Ezeken kívül problémát jelenthez a megfelelő munkaerő megtalálása $(9,7 \%)$, a fejlesztési pályázatok hiánya $(3,9 \%)$, a beszállítókkal kapcsolatban fellépő problémák kiküszöbölése $(3,1 \%)$ és a kiszámíthatatlan jogi környezet (1,8\%). (3. ábra) 


\section{3. ábra: A legfontosabb kihívások a közeljövőben a cégek számára (n=187)}

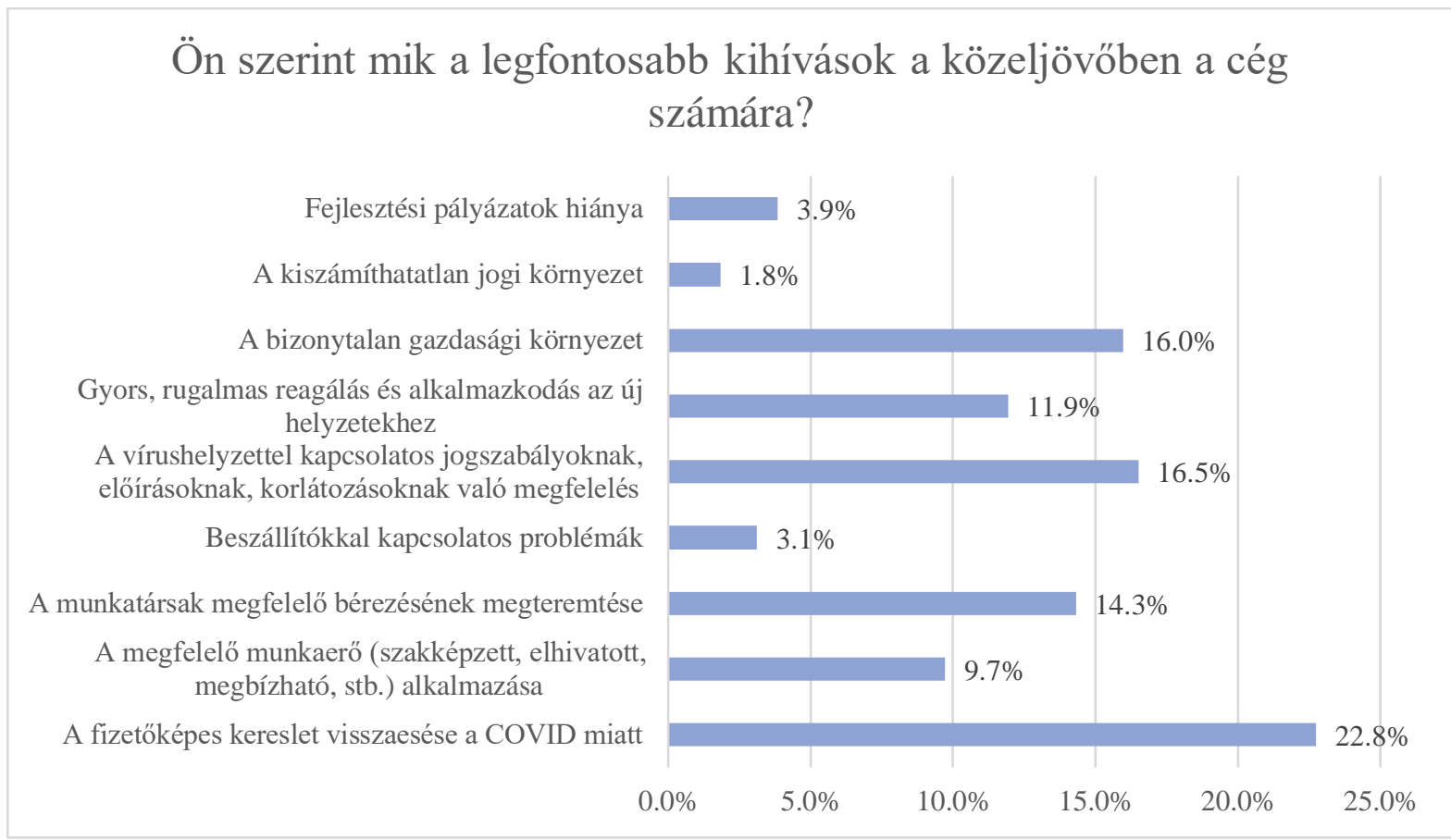

Forrás: Saját szerkesztés.

Miután a megkérdezettek kiválasztották a legfontosabb kihívásokat a közeljövőben, értékelniük kellett, hogy milyen kihívások léphetnek fel a vállalkozás életében közép- és hosszútávon. A kérdés nyitott volt, ezért a válaszadónak magának kellet megfogalmazni azt, hogy milyen nehézségekkel (kihívásokkal) számol a következő években. A leginkább jellemző probléma a járvány miatt kialakult helyzet átvészelése, túlélése és kilábalás (37\%). Ezzel kéz a kézben jár a turizmusfejlesztés, a gazdasági növekedés fenntartása, a régió választékának és tevékenységi körének bővítése $(24,4 \%)$, illetve a fizetőképes kereslet visszaesése $(15,7 \%)$.

Fontos megemlíteni, hogy bár nagyon sok kihívást a COVID-19-nek köszönhetünk, a kérdöívből is kiderül, hogy a régió már a vírus elött is küzdött hasonló kihívásokkal, mint például: gyenge gazdasági környezetben való fennmaradás; új területek bevezetés és szélesebb profil kialakítása; terjeszkedés. Ahogyan rövidtávon, úgy közép- és hosszútávon is problémát jelenthet a megfelelö munkaerő megtalálása $(9,4 \%)$, a munkatársak megfelelő bérezésének megteremtése $(7,1 \%)$ és a fejlesztési pályázatok hiánya $(0,8 \%)$. Az elöző ábrán megjelenő kihívásokhoz képest közép- és hosszútávon megjelenik még a növekvő versenyhelyzet okozta nehézségek kihívása, a versenyképesség fenntartása $(3,9 \%)$, illetve a megfelelő marketingkommunikációs stratégia kidolgozása $(1,6 \%)$.

A saját cég helyzetének értékelését követően a válaszadóknak a Dél-Dunántúli Régió vendéglátására váró kihívásokat kellett összegezniük. Ugyancsak nyitott kérdés keretében kellett a válaszokat megfogalmazniuk. Az eredmények alapján egyértelműen megállapítható, hogy a régió fejlesztése turisztikai szempontokból és a szezonalitás kiküszöbölése $(32,1 \%)$ a legfontosabb kihívások közé sorolható. A válaszokból kiderül, hogy a megkérdezettek szerint fontos lenne egy szélesebb profil kialakítása, új termékek és szolgáltatások bevezetése a régióban és a terjeszkedés. 
Régiószinten is eröteljes hatása van a kialakult vírushelyzetnek, de a régió elmaradása a többi régióhoz képest (mind szolgáltatásokban, mind bérezésben) nem új keletü probléma, hisz korábban is gyenge volt a régió jelenléte a hazai és nemzetközi piacon. Az ábrára visszatekintve a kihívások közé sorolhatjuk még a járvány miatt kialakult helyzet túlélését $(21,9 \%)$, a fizetőképes kereslet visszaesését $(16,1 \%)$, a vevői bizalom újbóli kiépítését $(10,2 \%)$, illetve a megfelelő munkaerő megtalálásának nehézségét $(5,8 \%)$. A megkérdezettek szerint próbatétel elé állíthatja a régiót a megfelelő bérezés megteremtése $(4,4 \%)$, egy egységes érdekképviselet kialakítása $(3,6 \%)$, a fejlesztési pályázatok hiánya $(2,2 \%)$, a megfelelő marketingkommunikációs stratégia kialakítása és a magasabb vendégéjszakaszám elérése (1,5-1,5\%), illetve az akadálymentesítés is $(0,7 \%)$.

A legfontosabb kihívások összefoglalását követöen a legfontosabb fejlesztések értékelése következett a kitöltők számára. Az új szolgáltatások és eszközök bevezetése (45,9\%) kulcsfontosságú lehet a cégek számára a közeljövőben. Lényeges fejlesztési pontok még a modernizálás, technológiai fejlesztés, felújítás és bővítés $(21,3 \%)$, a humánerőforrás fejlesztése $(13,1 \%)$, a marketing és arculattervezés $(9,8 \%)$, az IT részleg fejlesztése $(8,2 \%)$ és a vendégkör bővítésének $(1,6 \%)$.

\subsection{A fogyasztói szokások változása, új keresleti trendek a vendéglátásban}

A következőkben a vendéglátásra ható trendeket kellett értékelni a kitöltőknek abban a tekintetben, hogy milyen mértékben fogják befolyásolni a hazai vendéglátást a közeljövőben. A megkérdezetteknek válaszaikat egy 1-től 5-ig terjedő skálán kellett meghatározniuk, ahol a következő értékek szerepeltek: 1: egyáltalán nem érinti; 2: érinti, de nem lesz nagy hatással rá; 3: érinti és kismértékben hatással lesz rá; 4: jelentős hatást gyakorol rá; 5: meghatározó kérdéssé válik. A fogyasztók különleges gasztronómiai élmények iránti igényének növekedése a kitöltők közel fele $(46,1 \%)$ szerint jelentős mértékü befolyásoló értékkel fog rendelkezni a hazai vendéglátásban a közeljövőben, a gasztroturizmus erősödése pedig a kitöltők 44,7\%-a szerint jelentős hatást gyakorolhat a hazai vendéglátásra. 38,8\%-a kitöltőknek úgy gondolja, hogy jelentőst hatást gyakorol a regionális ételek iránti érdeklődés növekedése a vendéglátásukra. A street food növekvő térhódítása is egyértelmü, a kitöltők 90\%-a a 3-as, 4-es vagy 5-ös skálát választotta, ahogy az organikus élelmiszerek előretörése, illetve az egészségtudatosság elterjedése az étkezésben is megkérdőjelezhetetlennek tünik. Utóbbihoz kapcsolódik az ételallergiát, étel-intoleranciát, különféle diétákat figyelembe vevő ételek jelenlétének igénye a vendéglátóhelyek kínálatában, mely szintén igen magas százalékos aránnyal jelenik meg a válaszok között. A vegetarianizmus különböző formáinak térhódítása sem elhanyagolható. A közösségi média szerepének erösödése a gasztronómiai marketing területén meghatározó lesz a hazai vendéglátásban a kitöltők 45,4\%-a szerint. További 38,5\% gondolja, hogy mindenképpen jelentős hatása lesz a trend megjelenésének, ahogy a környezettudatosságot, fenntarthatóságot preferáló fogyasztói csoportok befolyásának növekedése is szignifikáns lesz a vendéglátó szektorban, a helyi termékek szerepének felértékelődésével együtt. 


\section{4. ábra: A vendéglátásra ható trendek.}

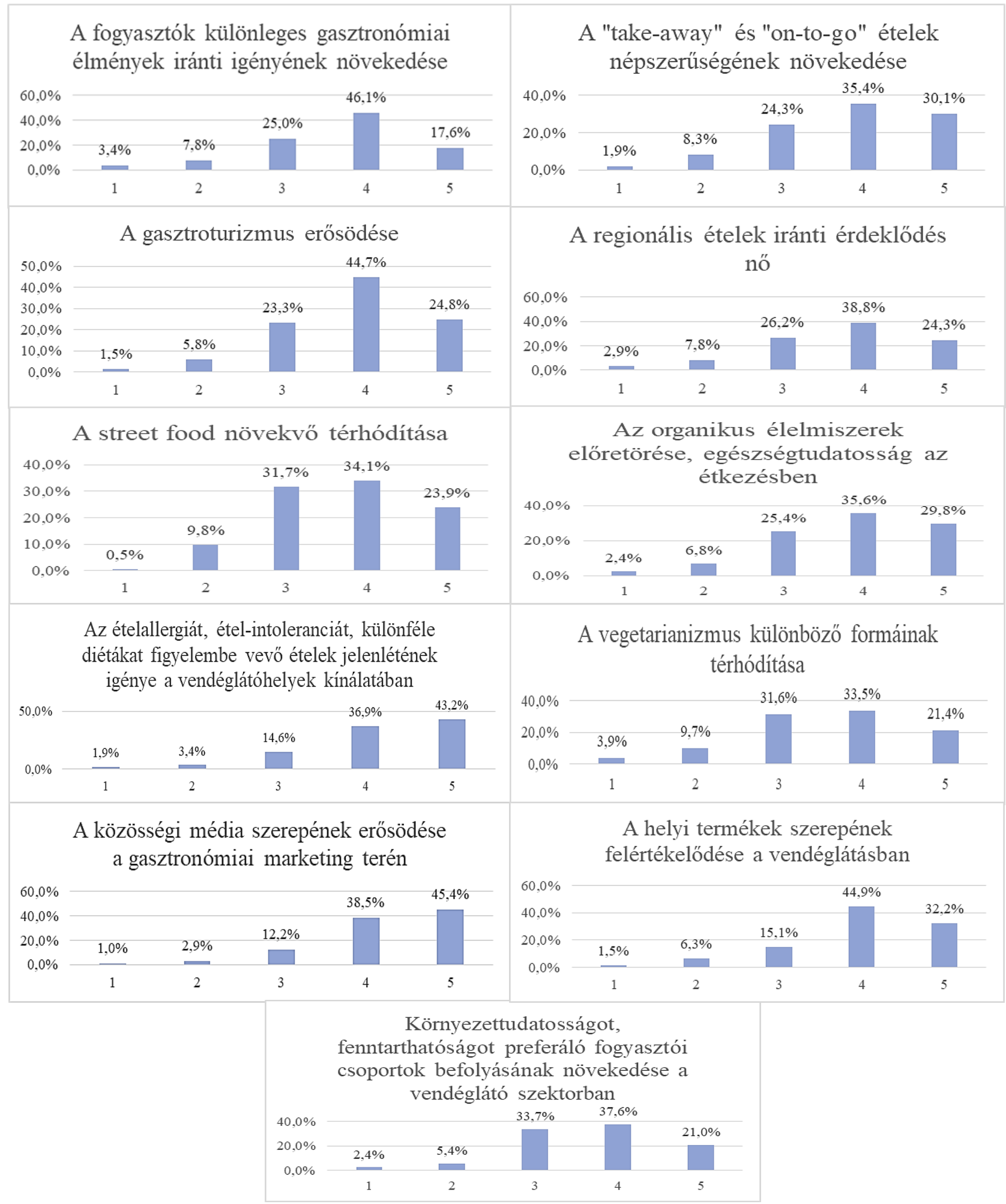

Forrás: Saját szerkesztés.

\subsection{A hazai fogyasztók attitűdjének értékelése}

A kérdőív következő szakaszában azt vizsgáltuk meg, hogy a következő állítások mennyire jellemzőek a hazai fogyasztókra. A kitöltőknek válaszaikat egy 1-től 5-ig terjedő skálán kellett megadniuk, ahol az 1-es azt jelentette, hogy egyáltalán nem ért egyet adott állítással, az 5-ös pedig 
azt, hogyha teljes mértékben egyetért az állítással. Ezen felül megadtunk egy 0 -s lehetőséget is azoknak, akik nem akartak vagy nem tudtak válaszolni a kérdésekre.

Az első blokk a kijárási korlátozás/veszélyhelyzet alatt és következtében bekövetkezett változásokat mutatja be (5. ábra). Például a hazai fogyasztókban felértékelődött a lakóhelyükhöz közeli vendéglátóhelyek látogatása, de a fogyasztási és étkezési szokásaik nem változtak érdemben. Az online beszerzéssel történő fogyasztási lehetőségek térnyerése elég szignifánsan jelenik meg a változások között. Ahogy azt is megállapíthatjuk, hogy a bezártság felerösítette a hazai fogyasztókban azt az érzést, hogy a minőségi étkezés és a gasztronómiai élmények fontos alakítói az életminőségünknek. Ehhez kapcsolódik, hogy a kitöltők negyede $(25,4 \%)$ inkább egyetért azzal, hogy a hazai fogyasztók igyekeznek a jelenlegi helyzetben online applikációkkal és virtuális megoldásokkal pótolni a kiesett élményeket. A vendéglátóhelyek házhozszállítási szolgáltatásainak sikeressége is szignifikáns eredményt mutat.

\section{5. ábra: Kijárási korlátozás/veszélyhelyzet alatt és következtében bekövetkezett változások}

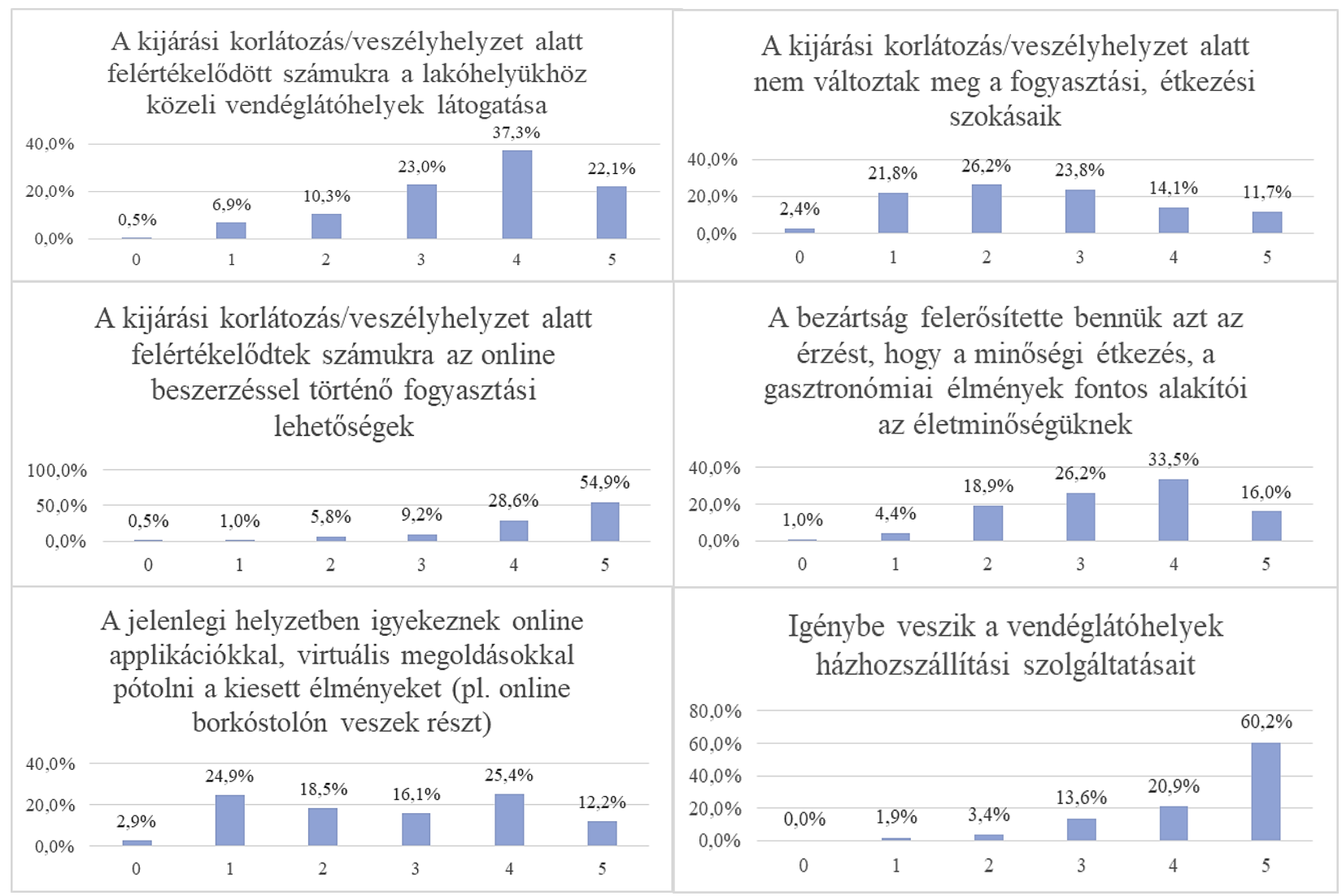

Forrás: Saját szerkesztés. 
A következö állításoknál azzal a feltevéssel éltünk, hogy véget ér a mostani járvány, és minden visszaáll a régi kerékvágásba. Ennek tekintetében kellett eldönteniük a megkérdezetteknek, hogy mennyire értenek egyet az adott állításokkal. Az előzőekhez hasonlóan, egy 1-től 5-ig terjedő skálán kellett megadni a válaszokat, ahol az 1-es skála az állítással egyáltalán egyet nem értést jelentette, az 5-ös skála pedig a teljes mértékü egyetértést. A válaszadóknak lehetőségük volt egy 0-s skálát is megjelölni abban az esetben, ha nem tudtak vagy nem akartak válaszolni a kérdésre.

A megkérdezettek 24,9\%-a teljes mértékben egyetért azzal, hogy az anyagi helyzetük megváltozása miatt a hazai fogyasztók egy ideig biztosan nem fognak tudni ugyanannyit a vendéglátóhelyekre járni, mint eddig, de még a kitöltők 27,8\%-a is inkább egyetért ezzel az állítással. Ugyanakkor a kitöltők közel negyede $(24,5 \%)$ teljes mértékben egyetért azzal, hogy a hazai fogyasztók igyekeznek bepótolni az elmaradt élményeket. Abban a kérdésben, hogy a járvány elmúltával biztosan meg fognak változtatni a fogyasztók étkezési szokásai egyelőre nincs egyértelmü válasz. Nagyjából egyforma mértékben fognak közeli és távoli vendéglátóhelyeket vagy gasztronómiai programokat felkeresni. Egyre több olyan fogyasztó lesz, aki a vendéglátásban a komplex élményt keresi, valamint a vendéglátás terén is preferálni fogják-e környezettudatos megoldásokat nyújtó szolgáltatókat. A hazai fogyasztók a jövőben, éttermi fogyasztásaik során is, felelősségteljesebben fognak viselkedni, valamint egyre több olyan fogyasztó lesz, akik a vendéglátásban a komplex élményt keresik. A hazai fogyasztók úgy vélik, a vendéglátás hozzájárul az emberek jó közérzetéhez és életminőségéhez, a vendéglátás szolgáltatásainak igénybevételével az emberek boldogabbak lesznek. Azonban azt sem szabad elfelejteni, hogy a kitöltők szerint a hazai fogyasztók nagy része még mindig olcsón szeretne sokat enni. A megkérdezettek 34,5\%-a teljes mértékben egyetért az állítással, 28,2\% egyetért vele, $17 \%$ a kényelmi középértéket választotta. 


\section{6. ábra: Jövőbeli trendek és szokások}

Az anyagi helyzetük megváltozása miatt egy ideig biztosan nem fognak tudni ugyanannyit vendéglátóhelyekre járni, mint eddig

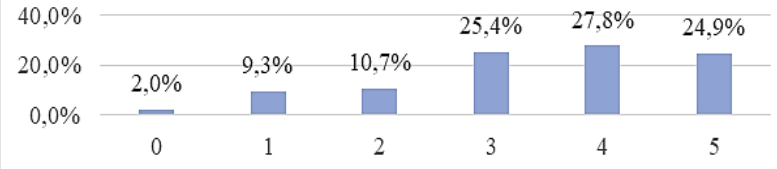

A járvány elmúltával biztosan meg fognak változni az étkezési szokásaik

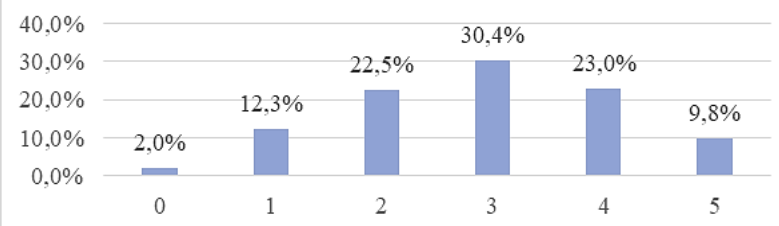

Ugyanolyan mértékben fognak távolabbi gasztronómiai programokra utazni, mint a veszélyhelyzet előtt

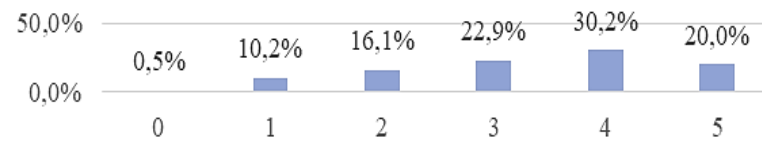

A vendéglátás terén is preferálni fogják a környezettudatos megoldásokat nyújtó szolgáltatásokat

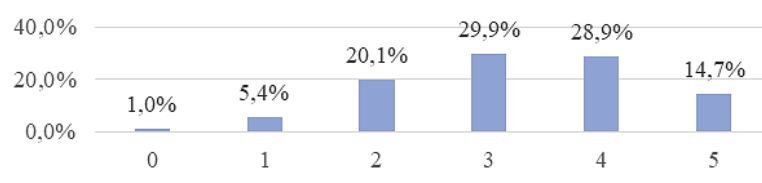

A vendéglátás szolgáltatásainak igénybevételével az emberek boldogabbak lesznek

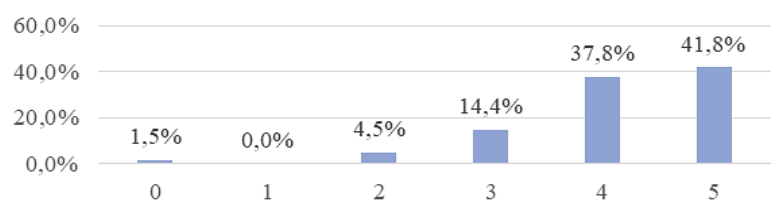

Igyekeznek azonnal bepótolni az elmaradt élményeket

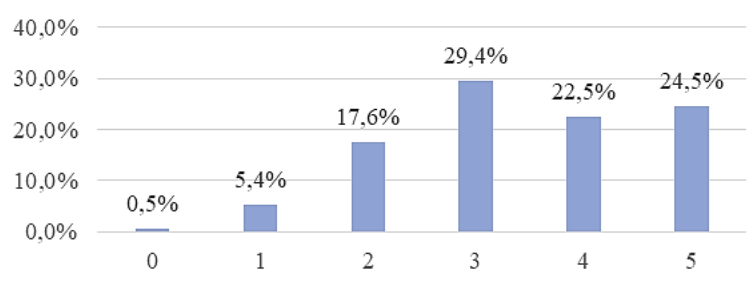

Felértékelödik számukra a környezetükben található, a lakóhelyükhöz közeli vendéglátóhelyek, gasztronómiai programok látogatása

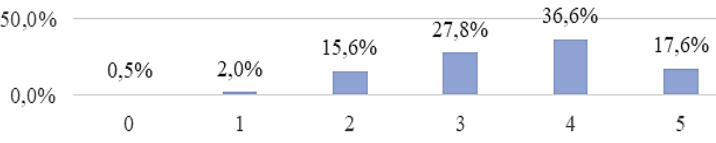

Egyre több lesz az olyan fogyasztó, aki a vendéglátásban a komplex élményt keresi

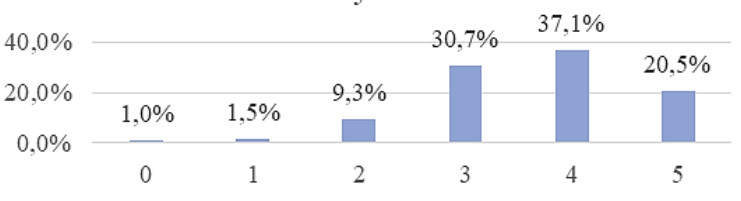

A vendéglátás hozzájárul az emberek jó közérzetéhez, életminőségéhez

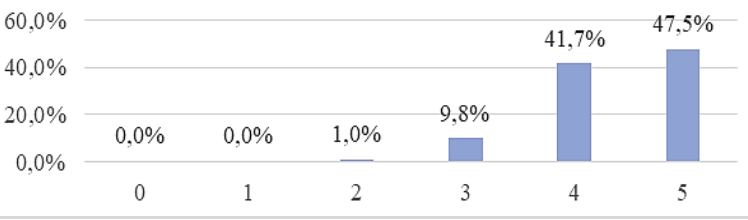

A fogyasztók nagy része még mindig olcsón szeretne jó sokat enni

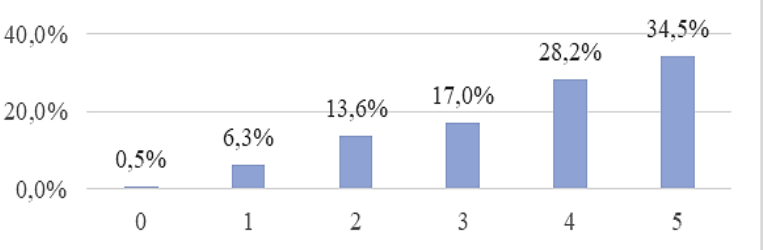

A jövőben az éttermi fogyasztásaik során felelösségteljesebben (a környezetre, a helyi lakosokra jobban odafigyelve) fognak viselkedni

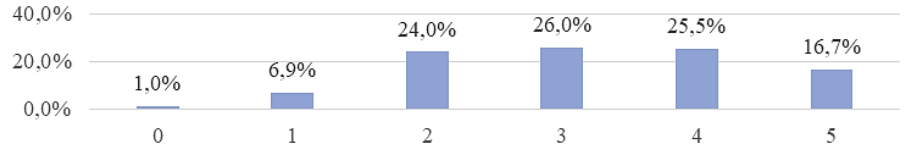

Forrás: Saját szerkesztés. 


\section{Összefoglalás}

Jelen kutatásunk előzményeként, a hazai és a nemzetközi szakirodalom feldolgozásával összegző anyag készült a turizmus jövőjéröl (CSAPÓ - TÖRÖCSIK 2020) és a vendéglátás jövőjéről (GONDA et al. 2020). Jelen kutatásunk értelmezhető az elözőek folytatásaként is, mikor is az érintett ágazat szakemberei véleményét ismerhettük meg. Megítélésünk szerint fontos, hogy a vendéglátás jövőbeni kihívásait és trendjeit ne csak szekunder forrásokon alapulva, hanem a gyakorlat legfontosabb szereplöit primer módszerrel (kérdőíves megkérdezés) tudjuk felmérni, így pontos képet kaphatunk a megkérdezett 200 érintett vállalkozó véleményéről, attitüdjeiről a jövő vendéglátása kapcsán.

Összefoglalásként elmondható, hogy a kérdőívet kitöltők leginkább alkalmazotti, vendéglátásban érintett cég vezetői vagy tulajdonosi minőségben szerepelnek; tevékenységüket tekintve föleg a melegkonyhás vendéglátóhelyek, kávézók üzemeltetésével és rendezvényszervezéssel foglalkozó cégek vettek részt a kutatásban; alapítás tekintetében megoszlik a kép; foglalkoztatást tekintve pedig föként a maximum 9 fő́t foglalkoztató mikrovállalkozások szerepelnek a tanulmányban. Emellett a megkérdezett cégek többsége több éves múltra tekint vissza, stabil piaci szereplönek tekinthető.

A vendéglátásra ható trendek tekintetében elmondhatjuk, hogy az ételallergiát, étel-intoleranciát, különféle diétákat figyelembe vevő ételek jelenlétének igénye a vendéglátóhelyek kínálatában és a közösségi média szerepének erősödése a gasztronómiai marketing területén a kitöltők szerint meghatározó kérdései lehetnek a hazai vendéglátásnak. Ezeken kívül az összes felsorakoztatott trend érinteni fogja a hazai vendéglátást, s kisebb vagy nagyobb mértékü hatása is lesz rá.

Ahogy a kutatási jelentés elején is leírtuk, a felmérésünk nem reprezentatív, azonban a 200-nál is nagyobb mintavétel és megkérdezés, a jelen tanulmány elemző fejezeteiben bemutatott eredmények véleményünk szerint megfelelő tudományos-szakmai alapot nyújtanak nemcsak egy kutatási jelentés elkészítésére, hanem további publikációk készítésére és jövőbeni kutatások inspirálására is. Úgy érezzük, hogy az itt közölt eredmények fontos információkkal szolgálnak a régiós, megyei és helyi döntéshozók számára is a vendéglátás további fejlesztése kapcsán a 2020. utáni időszak elkövetkező turizmusfejlesztési kihívásai terén.

A tanulmány a Pécsi Tudományegyetem megbízásából a GINOP-5.3.5-18-2019-00104 azonosító számú, „Kompetencia Központ létrehozása a turizmus-vendéglátás szakmacsoportban, Baranya megyében" címü projekt keretében készült.

\section{Irodalomjegyzék}

CSAPÓ, J. - LÖRINCZ, K. (2020): A turizmus gazdaságban betöltött szerepének és irányainak bemutatása Magyarországon a COVID-19 elött és után. Geometodika, 4(3).

CSAPÓ, J. - TÖRÖCSIK, M. (2020): A turizmus jövője, a nemzetközi és hazai turizmus legújabb trendjeinek elemzése elméleti és gyakorlati megközelítésben. Pécs, Magyarország: Pécsi Tudományegyetem Közgazdaságtudományi Kar (PTE KTK) (2020),65 p.

CSAPÓ, J. - GERDESICS, V. - GONDA, T. - RAFFAY, Z. - TÖRÖCSIK, M. (2018): EFOP3.6.1-16-2016-00004 „Átfogó fejlesztések a Pécsi Tudományegyetemen az intelligens szakosodás megvalósitása érdekében". Letöltve:

https://ktk.pte.hu/sites/ktk.pte.hu/files/images/tudomany/rendezvenyek/fogyasztas/efop_generaci ok_alaptanulmany_turizmus_2018_0.pdf, 2020. szeptember.29

FREYER, W. (2006): Tourismus. Einführung in die Fremdenvehrkersökonomie. Oldenburg Kiadó, 8. átdolgozott kiadás. 
FRIDDLE C. G. - MANGARAJ, S. - KINSEY, J. D. (2001): The food service industry: trends and changing structure in the new millennium. Working Paper 01-02, The Retail Food Industry Center, University of Minnesota

GÁSZNÉ BÖSZ, B. (2020): Dél-Dunántúl, a kulturális turisztikai régió? Turisztikai És Vidékfejlesztési Tanulmányok $5: 3$ pp. 74-90., 17 p. (2020)

GONDA, T. ; KAPOSI, Z. (2019): Pécs turizmusának első aranykora. Turisztikai És Vidékfejlesztési Tanulmányok 4 : 2 pp. 59-81., 22 p. (2019)

GONDA, T. (2016): A turisztikai termékfejlesztés elméleti alapjai. PTE, Kultúratudományi, Pedagógusképző és Vidékfejlesztési Kar, Szekszárd. 226 p. (ISBN:9789634291084)

GONDA, T. (2014):_A helyi termék turisztikai hasznosítása- a vidékfejlesztés új lehetősége: Potential use of local products in tourism - new ways for rural development. A Falu 29:(1):pp. 1723.

GONDA, T. - KAPOSI, Z. - RAFFAY, Z. - VARGA, G. (2020): A vendéglátás jövője. Pécs, Magyarország: PTE KTK Marketing és Turizmus Intézet (2020), 153 p.

GULD, Á. (2020): Étkezőshow-k a YouTube-on: A mukbang videók népszerüségének hátteréről egy kvalitatív befogadásvizsgálat tükrében. MARKETING ÉS MENEDZSMENT 54 : 1 pp. 29-42. , 14 p. (2020)

HALL, C. M. - SHARPLES, L. (2003): The consumption of experiences or the experience of consumption? An introduction to the tourism of taste. In: Hall, C. M.-Sharples, E.-Mitchell, R.Macionis, N.-Cambourne, B. (szerk.): Food Tourism around the world: Development, Management and Markets. Butterworth Heinemann, Oxford, 1-24.

HARSÁNYI, D. - HLÉDIK, E. (2020): Utazási célpontok kiválasztásának szempontjai a hazai borturizmusban. Marketing És Menedzsment 54 : 4 pp. 89-101. , 13 p. (2020)

MAGYAR TURISZTIKAI ÜGYNÖKSÉG (2017): Nemzeti Turizmusfejlesztési Stratégia 2030. Magyar Turisztikai Ügynökség, Budapest, 156.

MICHALKÓ, G. (2012): Turizmológia. Akadémiai Kiadó, Budapest

NEULINGER, Á. - BÁRSONY, F. - GJOREVSKA, N. - LAZÁNYI, O. - PATAKI, GY. TAKÁCS, S. - TÖRÖK, A. (2020): Fogyasztói jóllét a hazai alternatív élelmiszerellátási hálózatokban. Marketing És Menedzsment 54 : 3 klsz pp. 55-64. , 10 p. (2020)

PÁLFI, A. -AUBERT, A. (2019): Tourism Destination Management Organisations in the South Transdanubia Region. Turisztikai És Vidékfejlesztési Tanulmányok 4 : 1-2. klsz pp. 94-104. , 11 p. (2019)

POPOVICS, P. - SOÓS, M. - SZAKÁLY, Z. - KISS, V. Á. (2020): A személyes értékek, az idegen ízek és az újdonságkeresés közötti kapcsolat a hazai étkezési kultúrában. Marketing És Menedzsment 54 : 2. klsz pp. 19-27. , 9 p. (2020)

SOÓS, G. (2020): Az élelmiszer-fogyasztói szokások változása a COVID-19 vírus megjelenéséhez kapcsolódóan Magyarországon. Marketing És Menedzsment 54 : 3 pp. 15-27. , 13 p. (2020)

SZAKÁLY, Z. - POPOVICS, P. - SZAKÁLY, M. - KONTOR, E. (2020): A vásárlói magatartás elemzése az élelmiszer- és üzletválasztást befolyásoló tényezők alapján. Marketing És Menedzsment 54 : 2. klsz pp. 7-17. , 11 p. (2020)

SZIVA, I.- SIMON, J.- SZAKÁLY, O. (2017): Gastronomy as a new way of exploring tourism destinations, particularly in the case of Budapest. Marketing és Menedzsment, 51: Special issue ICC, 72-82. 
TÖRÖCSIK, M. - CSAPÓ, J. (2018): Fogyasztói trendek hatása a turizmusra. In: Csapó J. Gerdesics V. - Törőcsik M. (szerk.): Generációk a turizmusban. I. Nemzetközi Turizmusmarketing Konferencia, Pécsi Tudományegyetem Közgazdaságtudományi Kar, Tanulmánykötet. Pécs. pp. 822.

TUSOR, A. - SAHIN-TÓTH, GY. (2006): Gasztronómia, Budapest: Kereskedelmi és Idegenforgalmi Továbbképző Kft., 2006

VARGÁNÉ CSOBÁN, K. - SZABÓ, B. - GODÁNÉSÖRÉS, A. (2015): Gasztronómiai turizmus: nemzetközi kitekintés.

Letöltve:

https://dea.lib.unideb.hu/dea/bitstream/handle/2437/221520/file_up_TUDASGAZDASAG-

kiadvany-Csoban-Szabo-Sores.pdf?sequence=1\&isAllowed=y, 2020. szeptember. 29

ZÁVODI, B. - SZABÓ, G. (2019): The Correlation of the Fame of Wine Regions and Wine Gastronomy Festivals in the Pannon Wine Region. Turisztikai És Vidékfejlesztési Tanulmányok 4 : 1-2. klsz pp. 22-37. , 16 p. (2019) 